\title{
石炭の乾溜中に起る諸變化に就て(第一報) 石炭の加熱及乾溜に依る吸濕性の變化
}

\author{
伊木貞 雄 \\ （一）緒言
}

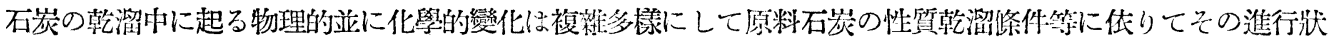

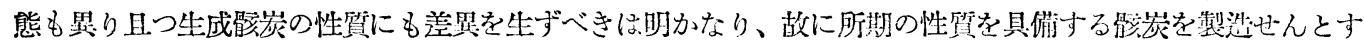
る原料炭の撰擇及處理、乾溜の裝置及方法の決定等に於て乾溜中に起る諸變化を究むることの樭際上必要なる は勿論、學術上にも石炭各成分の熱に對する性質を知り骹炭化の機满を明かにする等の意味に於てこの方面の

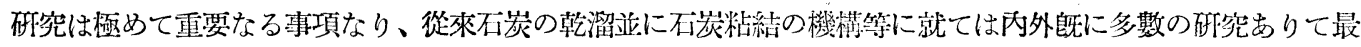

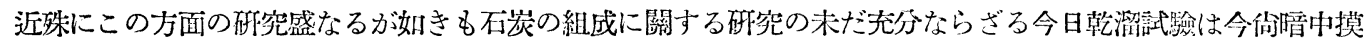
索の域を脫せず、粘結の機構の如きも粘結成分に關する諭議のみにては解決すべくももらず、备成分相互間の 關係に就て更に一一層の研究を要するものの如し、之等の意贿に於て石炭の乾溜中に起る物理的並に化學的諸變 化を各方面より更に精細に政究觀察することの必要なるを思はしむ、余は不炭の成分に重きをおき各成分の加

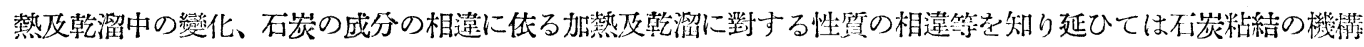
をも明にせんとする目的を以て成分の異る各種の試料郎ち天然炭化度の異る各階級の石炭文粘結性の異る各種

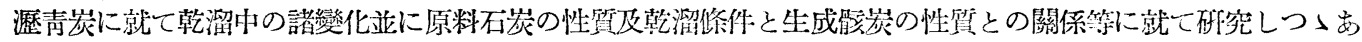
るが本郝告に於ては先づ各喠石炭の加熱及乾溜による吸濕性の變化に就て實驗したる結果を啹告せんとす 石炭それ自身の吸濕性及結合水分含有量は炭質と密接なる關係を存するものにしてこの點に關する研究少か らず、余も先に石炭の天然炭化度、粘結性及風化と吸濕性及結合水分との關係、並に石炭备成分の吸濕性等に就 て研究しこの方面に關して聊か明かにする所もりなり（本誌，昭 $3 ， 31 ， 1167 ＼mathrm{~ 昭 ~ 4, ~ 32 ， 1158) 、 然 る に 石 炭 ~}$

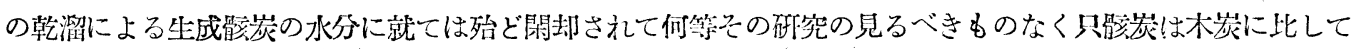
一般に吸濕性少く（通常 2 4\% 內外）又木炎と同樣炭化溫度の上帠と共に吸濕性低下寸る倾向あり且つ炭素

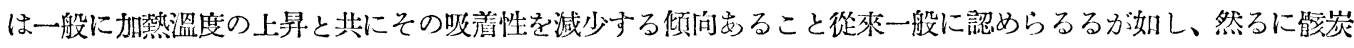

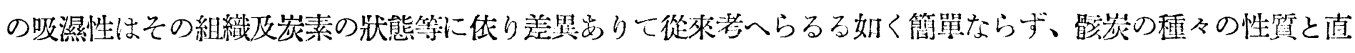

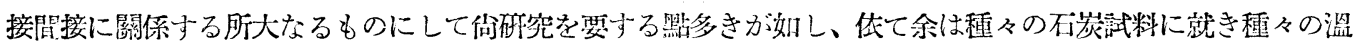
度に加熱及乾溜して得たるものの吸濕性に就て詿驗しその他の種々の性質變化との關係より乾溜中に起る變化 の一端をうかがはんとして次の實驗を行ひたり

\section{（二）試料及實驗方法}

本實驗に使用したる試料は余の從來の賽驗に使用しつつむる不炭の中より適當に撰定したる無烟炭、瀝垌炭 (粘結性の大中小種々のものを含む)褐炭及亞炭等を種々の溫度及時間、加熱及乾溜したるもの、米松鋸嘚を各 溫度にて乾溜したる木炭及び種々の炭素類を゙探れり、之等原料炭の分析結果は前報告に記述しむるを以て玆に は省略し加熱及乾溜の條件は實驗結果の部に於て詳記すべし 
水分定量法は一定細度（常に 100 日篩以下とせり）の粉碎試料 $1 \mathrm{~g}$ を時計皿にとり之を $30 \%$ の硫酸溶液を 容れたる恒濕槽（この槽內の關俰濕度常溫に於て約 76\% にして略當地 1 年間の平均濕度に等し）に一定重量 となる迄 (通常約 10 日間內外にて恒量となれり) 放置し之を乾燥器中 $105^{\circ} \mathrm{C} に 1$ 時間乾燥による重量の減 少を以て水分とする間接法に依りて行ひたり、次に實驗結果の大姴を記せん

\section{（三）實驗 結 果 の概 要}

上述の如き目的を以て行ひたる實驗事項は成分の異る各種石炭の加熱及乾溜溫度と生成䯘炭の吸濕性との關 係、瀝青炭の粘結性と生成䯚炭の吸濕性との關係、各種炭素類の吸濕性等なり

（1）各種不炭の加熱及乾溜溫度と吸第性との關係 試料は無煙炭として平壤炭、粘結性の大小種々 の瀝靑炭として三池炭（粘結性最大）高島炭（粘結性中）、明治炭（粘結性小）、豐國炭（非粘結性）、東見初褐炭 及知多亞炭の 7 種をとり之を 100 目篩以下に細粉したるものを磁製诗堝に入れて㥺を施し之を $100^{\circ} \mathrm{C} 、$ $200^{\circ} \mathrm{C} 、 300^{\circ} \mathrm{C} 、 400^{\circ} \mathrm{C} 、 500^{\circ} \mathrm{C} 、 600^{\circ} \mathrm{C} 、 700^{\circ} \mathrm{C} 、 800^{\circ} \mathrm{C} 、 900^{\circ} \mathrm{C}$ 及 $1000^{\circ} \mathrm{C}$ の各溫度に保てる電氣爐中に夫々 15 分間宛保ちて加熱或は乾溜をなし得られたる生成物を 100 目節以下に粉碎し之を上記硫酸恒濕槽にて恒量

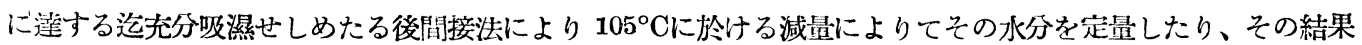
は第一圖に示す如し

\section{第一表 乾溜溫度と䯚炭の吸濕性との關係}

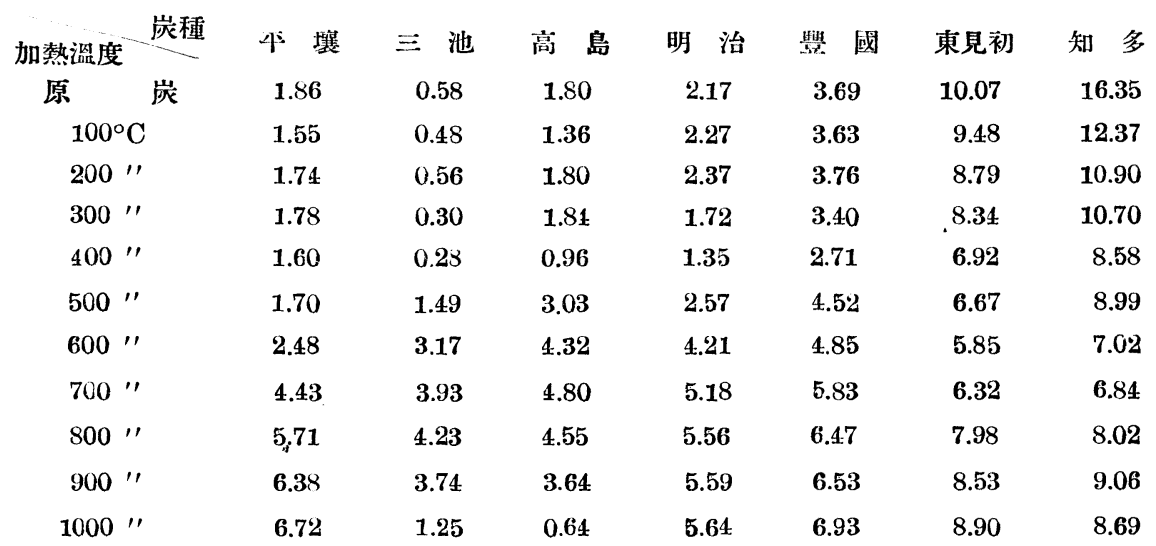

この結果を見るに何丸しの試料も加熱するに從つて初めはその吸濕性は減少し或る溫度に於て吸濕性最小の狀 態に達す、この溫度は魔青炭に就ては凡そ $400^{\circ} \mathrm{C}$ 附近なるが褐炭より亞炭に至るに從てつその最低吸濕性を呈 する溫度は次第に上昇し東見初褐炭に於ては $600^{\circ} \mathrm{C}$ 、知多亞炭に就ては $700^{\circ} \mathrm{C}$ 附近なり、又その吸濕性低下 の程度は天然炭化度低き若年炭及濋青炭に於ては粘結性小なる石炭程著しきも吸濕量の絕對值は体然原炭の吸 濕量の順序と同一なり、無煙炭にはこの變化最も小なり、次にこの最低吸濕性を呈する溫度を過れば何れの石 炭も著しく吸濕性の喤加を示寸も三池炭及高島炭の如き粘結性大なる石炭は $700 \sim 800^{\circ} \mathrm{C}$ 附近に於て再び吸濕 性の呧下を始め $1000^{\circ} \mathrm{C}$ 附近に至ればその吸濕性著しく小となる、則ち $700 \sim 800^{\circ} \mathrm{C}$ 附近に於て吸濕性最大の 䦓を有す、粘結性小なる瀝青炭及無喓炭、低級炭等にては $1000^{\circ} \mathrm{C}$ 迄の乾溜に於てはこの低下の傾向を示寸に 至らざれどもその吸濕曲線の次第に北斜緩漫となり而も粘結性大なる不炭程速かに水平狀態に近づく傾向を示 


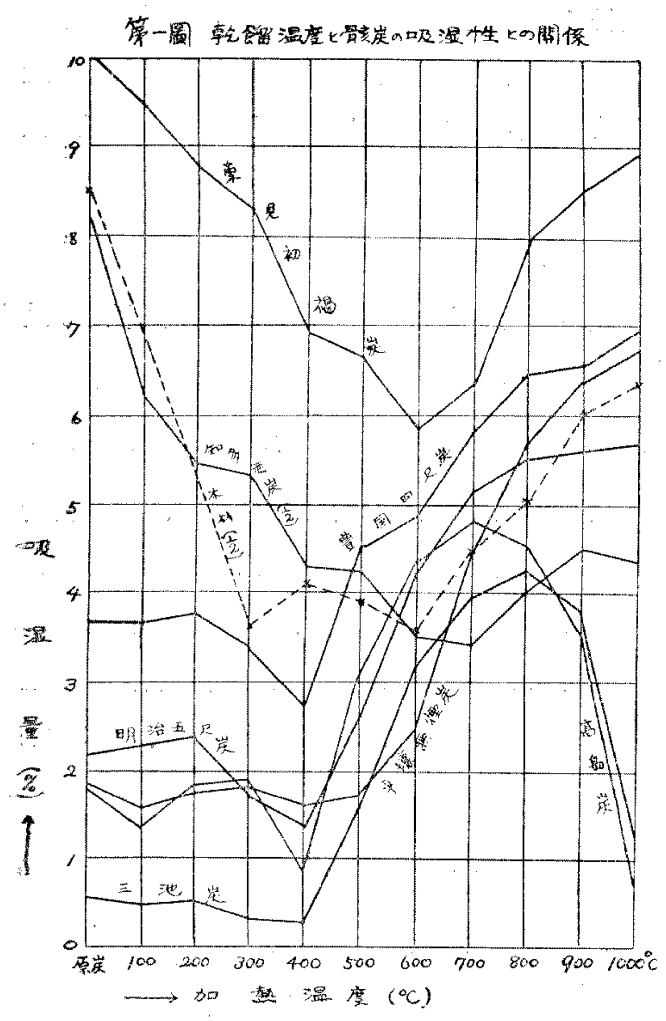

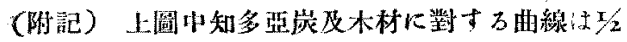
に縮めたるものなり

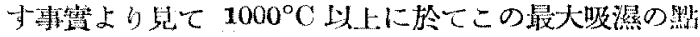
むるべくHつ粘結性大なるもの程この最大吸濕を示与 㵋度低きこと想像し得るが如し、而して舆煙炭老除

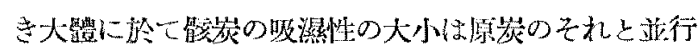
せるが如きも三池と商岛とは $8100^{\circ} \mathrm{C}$ 以にに於てはこ の順序逆となる結果を亦せり

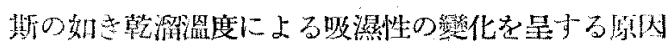

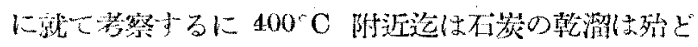
起らず、加熱のために䊀結性大なる不炭は軟化し粘結 性小なる不炭它その合有する所謂ビチェーメンの熔

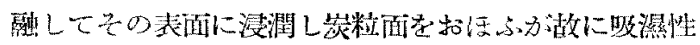
の代下を交すべく褐炭亞炭等に於てはその含存する フユーミン斩が比較的容易に尔解しために篦しくその 吸濕性の低下を來すべきこと想像に難からず、之等の

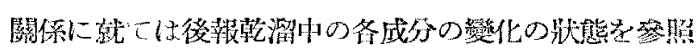
して考察すれしば信易に理解し得るが如し、吸蒸性最小 の渻度を過ぐれば何れの不炭む渚しくその吸濕性を堆

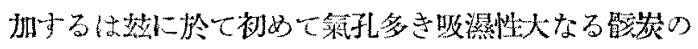
生成を意陎ずるのにして而も粘結性小なる不炭程こ の吸濕性大なるは不炭の成分によりて生成鲭嵌の性筫

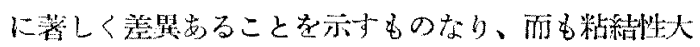

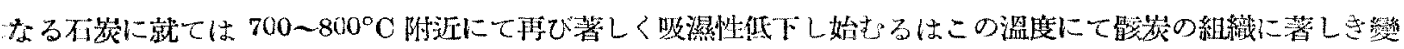
動起るか或は炭素の狀態に變化を來すかに传るべけれどもメッガー及ピストール爾氏の說 (R. Mezgar and F. Pistor, Gas und Wasserf., 1926, 69, 1061〜66)或はアグテ及リンカー兩氐の梳 (G. Agde und L. Linker (Brenn. Chem., 1929, 10, 88-99)の如く石炭中の油狀ビチューメン或は固形ビチューメンが分解して容易に不

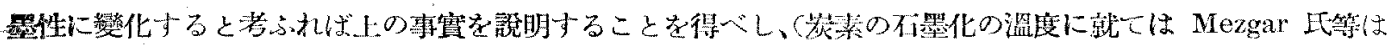
$800^{\circ} \mathrm{C}$ 附近とし Ruff 氏は $1100^{\circ} \mathrm{C}$ 以上とし通常 $800 \sim 900^{\circ} \mathrm{C}$ と考へらるるが如く又 Mezgar 氏等は油获 ビチューメンの分解物が石墨化容易なりとするに反し Agde 氏等告固形ビチっーメンが不墨化し易しと主張し

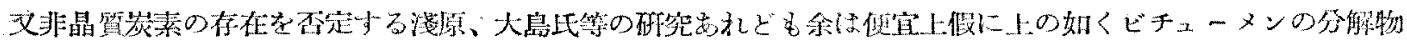

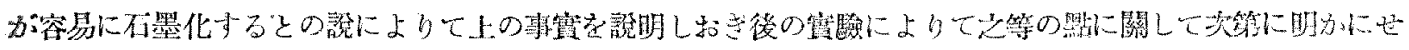
えことを期するるのなり

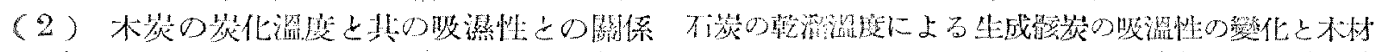

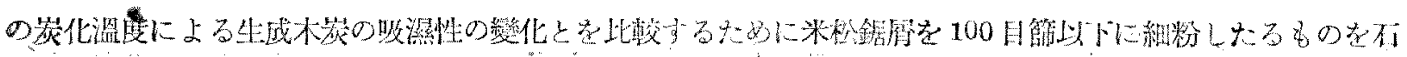

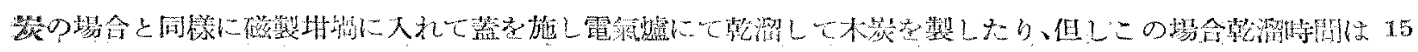

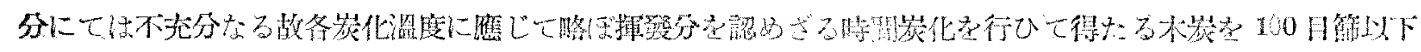




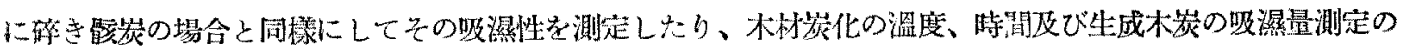
結果は第二表及第一圖 (點線にて示寸) に示持如し

\section{第二表 木炭の炭化溫度と吸潪性との關係}

\begin{tabular}{|c|c|c|c|c|c|c|c|c|c|}
\hline$\theta$ & 木材のま & $300^{\circ} \mathrm{C}$ & $400^{\circ} \mathrm{C}$ & $500^{\circ} \mathrm{O}$ & $600^{\circ} \mathrm{C}$ & $700^{\circ} \mathrm{C}$ & $830^{\circ} \mathrm{C}$ & $900^{\circ} \mathrm{C}$ & $1000^{\circ} \mathrm{C}$ \\
\hline & 分 & 250 & 80 & 35 & 20 & 15 & 8 & 7 & 5 \\
\hline & 17.19 & 6.85 & 8.13 & 7.84 & 7.33 & 8.94 & 10.02 & 12.12 & \\
\hline
\end{tabular}

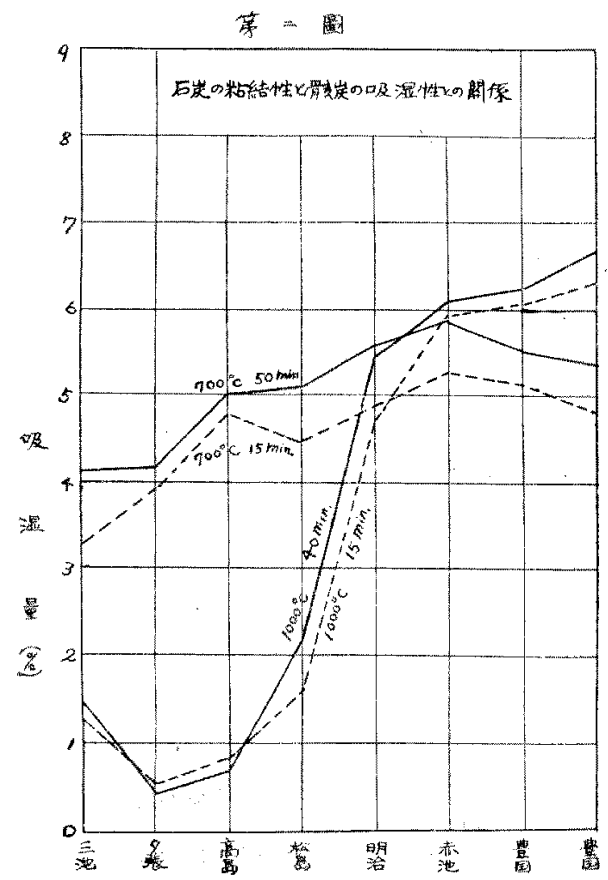

則ち炭化溫度 $600^{\circ} \mathrm{C}$ 迄は木炭の吸濕性は概して低下寸る 倾向を示しそれ以上温度の上昇と共に篔大す、但し $1000^{\circ} \mathrm{C}$ 以上の溫度に於て最大吸濕性の狀態に㩐し再低下する熙む るべきことは不炭の場合と同樣に考へ得べし、要するに木

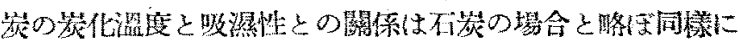
して特に褐炭亞炭の如き若年炭の場合に近きが昭し

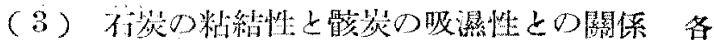
種不炭の乾溜溫度による生成䯘炭の吸瀑性つ變化の測定に

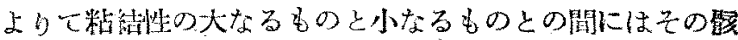

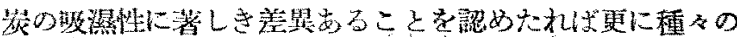
程度の秥結性を有する歴青炭をとり $700^{\circ} \mathrm{C}$ 及 $1000^{\circ} \mathrm{C}$ の

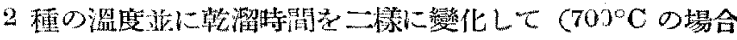
は 15 分及 50 分、 $1000^{\circ} \mathrm{C}$ の場合は 15 分及 40 分)上と

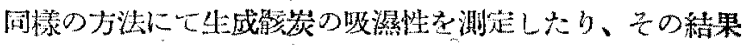
は第三表及第二㢦に示里

第三表 石炭の粘結性と䯚炭の吸濕性との關係

\begin{tabular}{|c|c|c|c|c|c|c|c|c|}
\hline $\begin{array}{lll}\text { 陚 } & \text { 料 } \\
\text { 粘 結 率 }\end{array}$ & 三 池 & $\begin{array}{l}\text { 夕 張 } \\
50\end{array}$ & 高息 & 28 & $\begin{array}{l}\text { 明 治 } \\
15\end{array}$ & 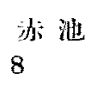 & $\begin{array}{l}\text { 輊 國 } \\
6\end{array}$ & $\begin{array}{c}\text { 豐 國 } \\
0\end{array}$ \\
\hline 吸瀑量 $\left(\begin{array}{l}700^{\circ} \mathrm{C} \\
15 \mathrm{~min}\end{array}\right)$ & 3.33 & 3.97 & 4.80 & 4.46 & 4.95 & 5.30 & 5.17 & 79 \\
\hline " $\left(\begin{array}{l}700^{\circ} \mathrm{C} \\
50 \min \end{array}\right)$ & 4.16 & 4.18 & 5.01 & 5.06 & 5.59 & 5.89 & 5.46 & \\
\hline " $\left(\begin{array}{l}1000^{\circ} \mathrm{C} \\
15 \mathrm{~min}\end{array}\right)$ & 1.34 & 0.45 & 0.82 & 1.63 & 4.71 & 5.98 & 6.03 & \\
\hline$"\left(\begin{array}{l}1000^{\circ} \mathrm{C} \\
40 \mathrm{~min}\end{array}\right)$ & 1.56 & 0.44 & 0.71 & 2.20 & 5.45 & 6.11 & 6.22 & \\
\hline
\end{tabular}

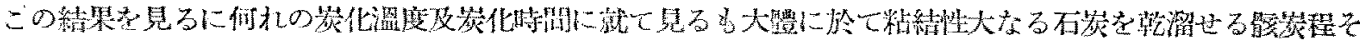

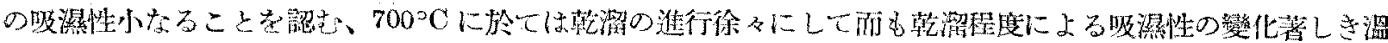

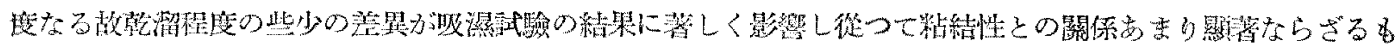

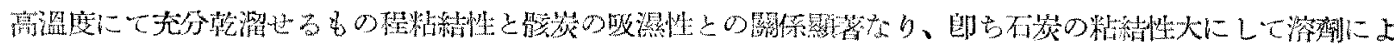

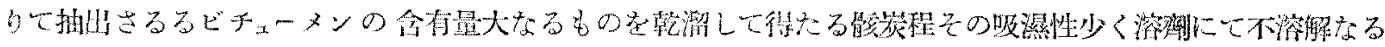

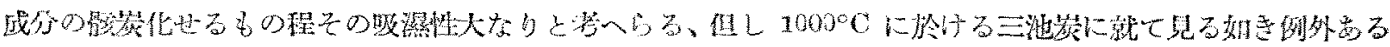

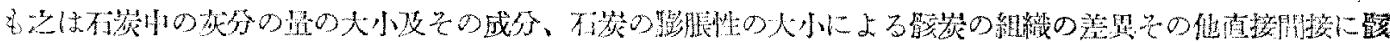


炭の吸濕性に影響する因丁の存在のために粘結性と能炭の吸濕性との關係に多少の不覞則を生ずべきことは哀

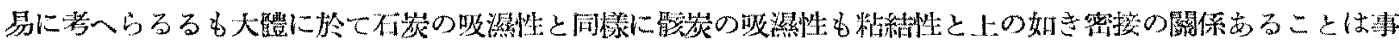
翼なり

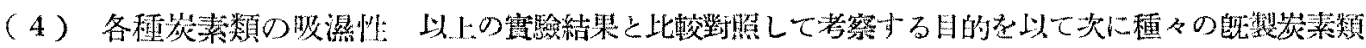

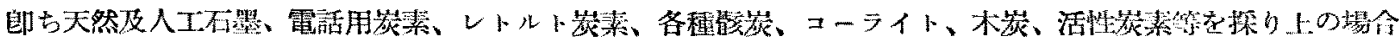
と全く同樣の方法にてその吸濕性を湘定したり、その結果は下表及第三䦌に示寸

第四表各種笼素類の吸濕性

試料試料關方万部事

1. 天 然石 墨

2. 人 造 石 墨

3. 電活用岸素

4. レトルト崖素 $\mathrm{A}$

5. レトルト崖素B

6. 製驖弊岸 $\mathrm{A}$

7. 製鐵峐岸 $\mathrm{B}$

8. 瓦斯㫘 崖

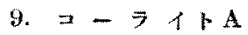

10. コー

11. 木宸

12. 砂 糖 宸

13. 活性荻䒺ダルコ

14. 活性岸素ノーリット
市貶僢狀石墨孝粉碎し使用寸

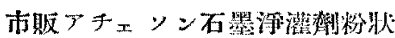

I. F. C. Carbone Delville. Transmitter 粒沜

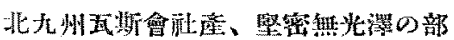

軟疏有光澤の部

同上

西.

八幡製鐵所產高自單味 S 式留孷、外侧堅密の部

同上

內侧疏筑の部

北九州瓦斯株式會社水本式瓦斯能炭

原料崎户宸

原料新原孷

市眅槱崖

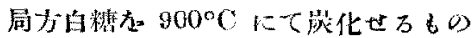

市販粉状製品

市貶粉狀製品
吸濕量(\%)

1.22

0.37

0.19

0.12

0.24

0.48

1.00

2.81

7.59

9.21

9.95

10.78

16.61

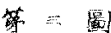

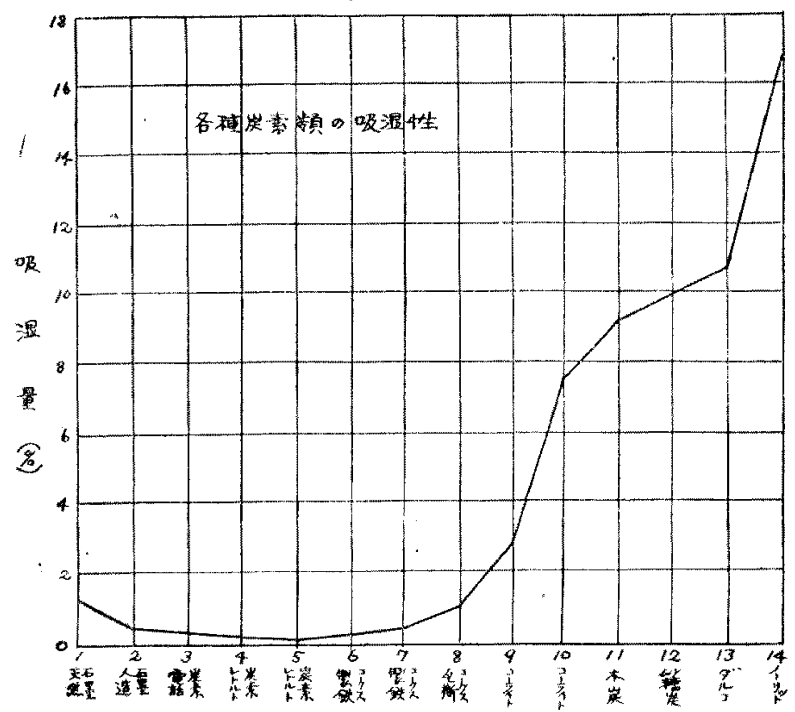

この結果を見るに炭化度の著しく淮行せ る不壆類の吸瀿性小なるは勿諭レトルト炭 素、製鐵繁炭、瓦斯䯚炭の順の如く商溫に 長封開加熱されたる順序に吸濕性增大寸る を認志、コーライト、木岑類の吸濕性は骹 炭類に比して遥加に大にして特に活性炭素 のそえい著しく大なることも自然なり、叉 レトルト炭素A 及 Bに於て見る如く柔軟 疏彭にして光濽むるピッチコークスの如き 部分は多孔性なるに保らず堅密無光澤の部 分上り㔭濕性少く同樣に製鐵䯚炭 A 及 B

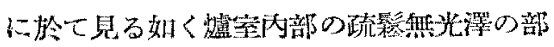
分より外側の堅缕なれども光濢むる部分が 吸濕性小なるを認も、之等の事害は不炭和 のビチ土ーメンの如き熔融成分の炭化せる 
もの程吸瀿性少き事を意味するものとすれば石炭の粘秸性と既の吸濕性との间に於ける上述の如き關係の存 すること蔩書きするものと云ひ得べし、少コーライト、㨏、活性炭素の如きが吸濕性大なるはその炭化溫 度の低き事その原料の性質及その特殊の處理方泆等より考察して賞然然るべきことと考へ得べし

（四）總括

各種石炭の炭化溫度と生成觓炭の吸瀿性との關係、木炭の炭化溫度と吸瀿性との關係、石炭の粘結性と生成

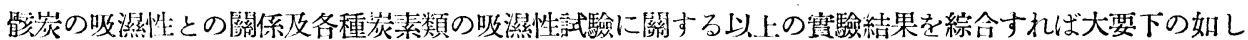

（1）各種石炭は何れぬ加熱によりて初めはその吸濕性低下し或溫度にて吸濕性最少の狀態に達寸、この溫度 は歴青炭に就ては $400^{\circ} \mathrm{C}$ 附近なるも褐炭亞炭に至るに從つて1:昇し褐炭には $600^{\circ} \mathrm{C}$ 亞炭には $700^{\circ} \mathrm{C}$ 附近な り)

（2）最低吸濕性を呈する溫度を過れば何れの石炭も急激にその吸濕性を增大するも粘結性大なる石炭に於て は $700^{\circ} \sim 800^{\circ} \mathrm{C}$ にて吸濕性最大の狀態に達し之より再低下し始屯、粘結性小なる瀝青炭、無煙炭、褐炭及亞 炭等に於ては $1000^{\circ} \mathrm{C}$ 迄にはこの猒態を呈するに至らず

（3）種々の溫度に炭化せる木炭の吸濕性は不炭の場合と略同樣にして特に褐炭亞炭の好き若年炭の場合に近 L

(4) 石炭の粘結性の大小とその乾溜生成䯚炭の吸瀿性との間には密接なる關係ありて粘結性大なる石炭を用 ひたる骸炭程その吸濕性は一般に小なり

（5）各種の既製炭素類の吸濕性を檢するに大體に於て炭化の程度の進行せる石黑類の吸濕性最小にしてレト ルト炭素、製鐵䯚炭、瓦斯䯚炭及コーライトの順に概して炭化溫度及時間の小なるもの程吸濕性大なり、又略 同一條件にて炭化せるものはビチューメンの分解物と考へらるる光澤むる部分程水分少し、無光澤の部分程水 分多き倾向を示寸

（6）之等の諸現象は石炭の天然炭化の程度及粘結性の大小による石炭の成分の相違並びに各成分の熱に對す る性質より考察して略了解し得ることを明かにせり

（明治專門學校應用化學科数室）（昭和五年六月六日受理）

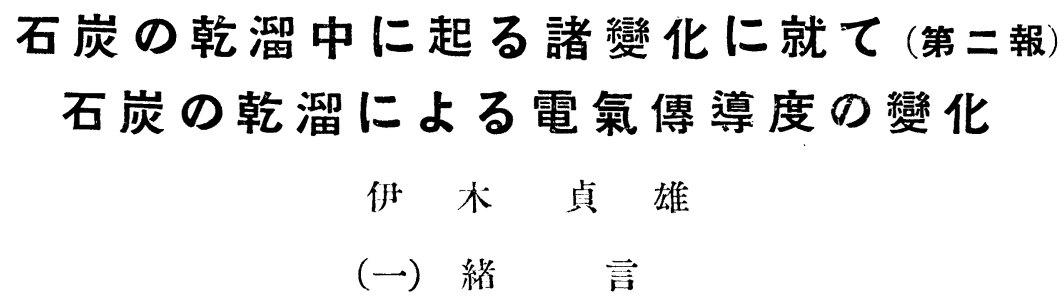

不炭はそのまっにては㱠ど全く遊耀炭素を含まず、複雜なる炭素化合物の集團にして事賽上全く電氣の不導 娟なるも之を乾溜するときはその分解に依りて遊㒕炭素を析出し䉆に電導性を得るを以て乾溜中の電氣傳導度 の變化を測定することは乾溜淮行狀態觀察の一方法たると共に生成矝炭の性質試驗の一助となるものなり、こ の意朱に於て余は光に石炭の低溫及高溫乾溜の進行途中に於ける電氯傳導度の變化を測定してこの間の事情を 略明かにするを得たり（本誌，眧 $4 ， 32 ， 367 ； 375$ )、然るにこの方法は粘結性小なる石炭に就ては何等困䧼な きも膨脹粘結性の石炭にありては加熱乾溜中に試料が著しく軟化膨脹して各粒子間の接觸犾態等に著しき變化 